\title{
Effect of APF Gel Application Time on Enamel Demineralization and Fluoride Uptake In Situ
}

\author{
Rita Sarmiento VILLENA ${ }^{1}$ \\ Livia Maria Andaló TENUTA ${ }^{2}$ \\ Jaime Aparecido CURY2 \\ ${ }^{1}$ Department of Community Dentistry, Dental School, Cayetano Heredia University, Lima, Peru \\ ${ }^{2}$ Piracicaba Dental School, University of Campinas, Piracicaba, SP, Brazil
}

\begin{abstract}
This in situ crossover and blind study was conducted to investigate the effect of professional acidulated phosphate fluoride (APF) gel application time on the subsequent inhibition of enamel demineralization. During 3 phases of 28 days each, 15 volunteers wore palatal appliances containing 4 enamel blocks, which were subjected to 3 treatment groups: not treated (control) and pre-treated with APF gel for 1 or $4 \mathrm{~min}$. Dental plaque was allowed to accumulate on the blocks and the appliances were immersed in $10 \%$ sucrose solution 3 times a day simulating a cariogenic challenge. After each phase, the blocks were removed to evaluate enamel demineralization and concentration of fluoride (F) remaining after the cariogenic challenge. F formed on enamel was determined in additional enamel blocks subjected only to APF gel application. APF gel was efficient in reducing enamel demineralization $(\mathrm{p}<0.05)$, irrespective of the application time $(\mathrm{p}>0.05)$. Also, the concentration of the $\mathrm{F}$ formed and retained on enamel was significantly higher after APF gel application $(p<0.05)$, but the effect of time of application was not statistically significant $(p>0.05)$. The results suggest that APF application for either 1 or $4 \mathrm{~min}$ is equally efficient to increase $\mathrm{F}$ concentration in enamel and reduce enamel demineralization.
\end{abstract}

Key Words: fluoride, acidulated phosphate fluoride, demineralization, enamel, time.

\section{INTRODUCTION}

Professional acidulated phosphate fluoride (APF) application is a well-known method used for dental caries prevention and its efficacy is clearly recognized on an evidence-based perspective (1). However, most of the currently followed clinical recommendations for pre- and post-fluoride (F) application have been established in the middle of the last century. Among these recommendations, 4 min has been suggested as the optimal time for $\mathrm{F}$ application (2), perhaps based on the approximate time that a $2 \%$ sodium fluoride aqueous solution takes to be absorbed by the tooth surface (3). However, no consensus has been reached regarding the time that should be used for F gel application (4). In fact, in a recent report (5) about evidence-based recommendations of professional applied topical $\mathrm{F}$, the clinical relevance of the application time was not considered.

The anticaries effect of professional $\mathrm{F}$ application depends on reaction products formed on enamel during the clinical treatment and their retention over time after the application. The formation of products on enamel is dependent on the concentration of $\mathrm{F}$ applied and the $\mathrm{pH}$ of the commercial product used.

Regarding $\mathrm{F}$ application time, most studies evaluating its relevance have been focused on $\mathrm{F}$ uptake by enamel and divergent results have been found. While some studies have shown differences between 1 and 4 min of application $(6,7)$, others have not $(8,9)$. However, although there seems to exist a relationship between $\mathrm{F}$ concentration on enamel after professional F application and the subsequent demineralization (10), in vitro studies have suggested that 4-min F application does not reduce enamel demineralization more that 1-min $\mathrm{F}$ application $(11,12)$. It is possible that the difference in the amount of $\mathrm{F}$ products formed on enamel during 1 or $4 \mathrm{~min}$ is not clinically relevant to render enamel more caries resistant.

Since placebo-controlled clinical studies are no longer applicable due to ethical reasons (13) and in

Correspondence: Prof. Dr. Jaime A. Cury, Avenida Limeira, 901, Caixa Postal: 52, 13414-903 Piracicaba, SP, Brasil. Tel: +55-19-2106-5302. e-mail: jcury@fop.unicamp.br 
situ studies have been proven sensitive to evaluate the efficacy of $F$ treatments on caries, the aim of this study was to evaluate in situ the effect of APF gel application time on the reduction of enamel demineralization and $\mathrm{F}$ formed and retained on enamel.

\section{MATERIAL AND METHODS}

\section{Experimental Design}

A crossover and blind in situ study was performed in 3 phases of 28 days each. Fifteen adult volunteers in good oral and general health took part in this study after signing an informed written consent form (Resolution no. 196 from National Health Council, Ministry of Health, Brasília, DF, Brazil; March 10, 1996). Only volunteers with a minimum non-stimulated salivary flow rate of 0.4 $\mathrm{mL} / \mathrm{min}$ were considered eligible to participate (mean flow rate $=0.66, \mathrm{SD}=0.16$ ). The volunteers wore palatal appliances containing enamel blocks pre-treated or not with APF gel. They were randomly assigned to one of the following treatments in each phase of the crossover study: 1: Control (non-treated); 2: APF - $1 \mathrm{~min}$; and 3: APF - 4 min. All volunteers participated in the 3 phases of the study.

Enamel blocks $(4 \times 4 \times 2 \mathrm{~mm})$ were prepared from unerupted human third molars, which were polished flat to remove about $50 \mu \mathrm{m}$ of the outer enamel surface (14). The blocks were randomly distributed into the treatment groups. Six blocks were placed in each palatal appliance, 4 of them fixed in a recess made in the acrylic resin (14) and the other 2 fixed with wax onto the acrylic surface.

The volunteers received 1- or 4-min APF gel (1.23\% F, pH 3.6-3.9; Nupro ${ }^{\circledR}$; Dentsply Ind. e Com. Ltda., Petrópolis, RJ, Brazil) application, with the appliances in their mouth. APF gel was applied to the volunteers' teeth using disposable trays and a cotton swab was used to carry the gel to the area of the appliance containing the 6 enamel blocks. After 1 or 4 min, the excess of gel was expectorated and volunteers were instructed not to drink or eat anything for $30 \mathrm{~min}$. Immediately after application and expectoration of the gel, the 2 blocks fixed with wax onto the appliances were removed for analysis of the $\mathrm{F}$ formed in enamel. These blocks were thoroughly rinsed with distilled water for 2 min to remove the excess gel and were kept in a moist environment until the analysis of $\mathrm{F}$ in enamel. Three hours after APF application, plastic meshes were fixed over the other 4 blocks in the palatal appliance to allow plaque accumulation (15) and the volunteers wore the appliances for 28 days, removing only for eating or drinking, when they were kept moist in a plastic box. At the main mealtimes, 3 times a day, the appliances were also removed and immersed for $10 \mathrm{~min}$ in $10 \%$ sucrose solution (prepared immediately before use by mixing a $10 \mathrm{~g}$ sugar sachet with $100 \mathrm{~mL}$ of water). During a 10-day pre-experimental period, the washout period and the experimental phases, the volunteers brushed their natural teeth and the appliance with non-fluoridated toothpaste and were instructed to avoid the area containing the plastic meshes to prevent plaque disturbance. All volunteers lived in a city with optimally fluoridated water (0.6-0.8 ppm F).

At the end of each phase, the 4 blocks were removed and cleaned with a soft-bristle brush. Enamel demineralization was determined in two of them and $\mathrm{F}$ retained in enamel was analyzed in the other two. At least 7 days of washout period was allowed between each experimental phase. New appliances containing a new set of enamel blocks were made for the next phase.

\section{Enamel Demineralization Assessment}

Enamel demineralization was determined by cross-sectional microhardness (CSMH) because there is a high correlation ( 0.91 ) between enamel microhardness and $\%$ mineral in caries lesion (16). Briefly, the blocks were sectioned longitudinally through the center, embedded in acrylic resin in such a way that the cut section was exposed and could be polished. The indentations were made at $10 \mu \mathrm{m}$ from the outer enamel surface up to $90 \mu \mathrm{m}$. Three rows of indentations were made, one in the central region of the dental block and the other two at $100 \mu \mathrm{m}$ on both sides of the first row, using a Shimadzu HMV 2000 tester (Shimadzu Corporation, Kyoto, Japan) and Knoop diamond under $25 \mathrm{~g}$ load for $5 \mathrm{~s}$. The mean values at all measuring points at each distance from the surface from the 2 blocks were then averaged. The Knoop hardness number (KHN) values were converted to mineral contents (vol\%) (16).

\section{Fluoride Determination in Enamel}

Total $\mathrm{F}$ was determined after acid etching extraction (17). Five enamel layers were sequentially removed from the 2 blocks only subjected to APF application to 
determine $\mathrm{F}$ formed and from 2 enamel blocks subjected to the cariogenic challenge to evaluate retained F. In addition, $\mathrm{F}$ was determined in other non-treated 30 blocks in order to estimate the baseline values ( $\mathrm{F}$ before). Each enamel block was immersed in $0.25 \mathrm{~mL}$ of $0.5 \mathrm{M} \mathrm{HCl}$ for 30, 30, 30, 60 and $60 \mathrm{~s}$ under agitation (14). An equal volume of TISAB II (1.0 M acetate buffer $\mathrm{pH} 5.0,1 \mathrm{M}$ $\mathrm{NaCL}$ and $0.4 \% \mathrm{CDTA}$ ) modified with $20 \mathrm{~g} \mathrm{NaOH} / \mathrm{L}$ was added to each solution containing the dissolved enamel layer. $\mathrm{F}$ measurements were performed using an ion-selective electrode Orion 96-09 and an ion analyser Orion EA-940 (Orion Research Inc., Boston, MA, USA). The amount of enamel removed ( $\mathrm{g}$ ) by each acid etching was calculated from the inorganic phosphorus concentration determined by light spectrophotometry, assuming its content in enamel to be $17.4 \%$ (14). Due to the density variation of caries lesions, the data ( $\mu \mathrm{g} \mathrm{F} / \mathrm{g}$ of enamel) were expressed per layer rather than as a function of depth (18). The mean values from the 2 blocks were averaged to obtain a single value per volunteer.

\section{Statistical Analysis}

The mean values from the 2 blocks were averaged in such a way that the experimental unit was the volunteer $(n=15)$. The significance of treatments was analyzed by analysis of variance and Tukey's test, but all data were transformed to $\log _{10}$ in order to fit the assumptions of homocedasticity and normal distribution of errors. Paired t-test was used to compare $\mathrm{F}$ formed and retained in enamel for each treatment group. For all statistical analysis, BioEstat 2.0 software was used and the significance level was set at 5\%.

\section{RESULTS}

Figure 1 shows mineral content ( $\% \mathrm{vol})$ in enamel after the cariogenic challenge, according to the treatment groups and the distance from the surface. APF gel applied either for 1- or 4-min was statistically more efficient than the control in reducing mineral loss up to $20 \mu \mathrm{m}$ from the enamel surface $(p<0.05)$. However, the differences between 1- and 4-min APF application times were not statistically significant $(\mathrm{p}>0.05)$ at any distance from the enamel surface.
Figure 2 shows the distribution of F concentration throughout the enamel surface. The comparison of groups before the cariogenic challenge showed a significantly higher $\mathrm{F}$ concentration formed up to the third enamel layer removed for blocks treated with APF for 1 or 4 min compared to the control group ( $\mathrm{p}<0.05$ ). However, no significant differences were found between the treatment groups $(\mathrm{p}>0.05)$. Accordingly, after the in situ challenge, a significantly higher $\mathrm{F}$ concentration in the first layer of enamel removed was found for blocks previously treated with APF for 1 or 4 min when compared to the control group $(\mathrm{p}<0.05)$, and without significant differences between them $(p>0.05)$. When the $\mathrm{F}$ concentration on enamel before and after the cariogenic challenge within each group was compared,

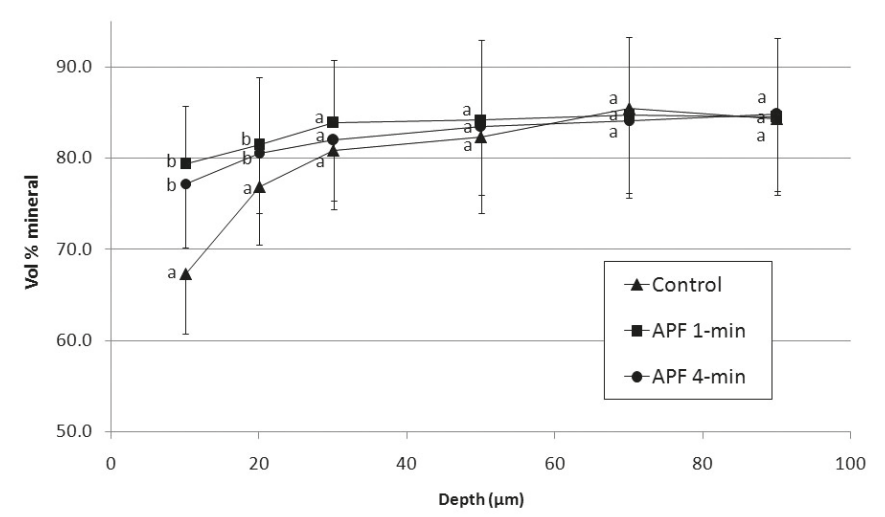

Figure 1. Mean $(n=15)$ of enamel mineral (vol\% mineral) at different distances from enamel surface (depth) according to the treatment groups. Bars indicate SE and the statistical significance between treatments at each distance is indicated by different letters $(p<0.05)$.

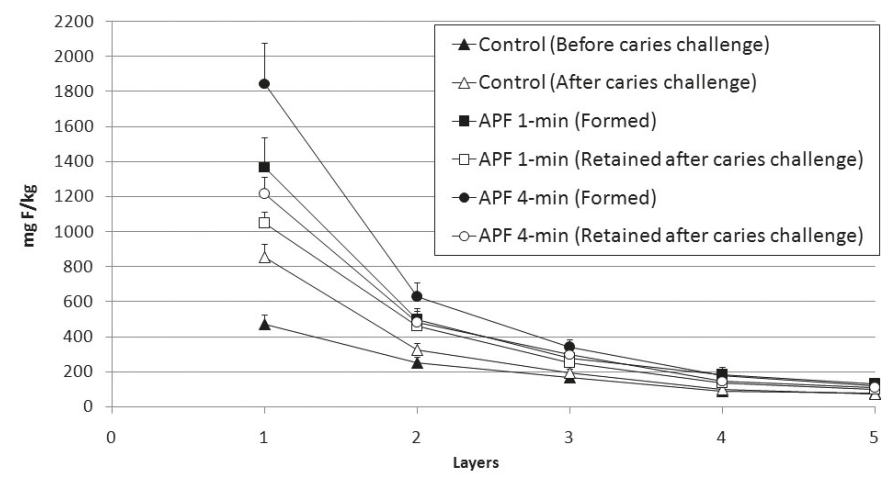

Figure 2. Mean $(\mathrm{n}=14)$ of fluoride concentration in enamel (mg F/kg) at the relative distance from enamel surface (layers) and according to the treatment and control groups. Bars indicate SE and the statistical significance is described in Results section. 
a significant increase in $\mathrm{F}$ concentration in the first 3 layers of enamel removed was found for the control group $(p<0.05)$. For groups treated with APF for 1 and 4 min, $F$ retained after the cariogenic challenge in the first enamel layer removed was significantly lower when compared to the $\mathrm{F}$ formed by APF application $(\mathrm{p}<0.05)$.

\section{DISCUSSION}

In situ studies have been considered as intermediate between in vitro and in vivo studies because they allow the control of some clinical variables related to caries development (19). In situ studies have been used for different purposes. Using this model, Delbem et al. (20) have previously evaluated the effect of water rinse on the anticaries effect of acidulated phosphate fluoride (APF) gel application.

In this in situ study, APF gel increased F concentration in enamel compared to the control irrespective of application time (Fig. 2), which is in agreement with the findings of in vitro investigations $(8,9,12)$. The $\mathrm{F}$ concentration formed on enamel by APF-gel application for 4 min was approximately $30 \%$ higher than that formed after 1-min application, but this difference was not significant to render enamel more resistant to demineralization. The findings can be explained by the fact that although there is a dose-response relationship between $\mathrm{F}$ formed on enamel and the decrease of demineralization, it is not linear (10).

Furthermore, after the 28-day cariogenic challenge, $\mathrm{F}$ concentration in enamel decreased in the APFtreated groups (Fig. 2). F concentration decreased by $24 \%$ and $34 \%$ when APF was applied for 1 or 4 min, respectively. This reduction has been found in vitro $(12,18)$ and in vivo $(15)$ and is due to the release of loosely bound $\mathrm{F}$ formed on enamel by APF treatment to the oral environment (10). On the other hand, F concentration in enamel not treated with APF increased after the cariogenic challenge. This could be explained by the exposure of volunteers to fluoridated water during the experiment, resulting in gain of $\mathrm{F}$ by enamel from environment, as shown in vitro (12) and in situ (14). Thus, this gain of $\mathrm{F}$ in the control group is a consequence of the physicochemical effect of $F$ during caries development.

Regarding enamel demineralization, APF gel application was efficient in reducing mineral loss because the vol\% mineral found for both treated groups was significantly higher than that for the control. This statistically significant effect of the treatments was observed up $20 \mu \mathrm{m}$ from the surface, indicating that a shallow caries lesion was formed. It can be explained by the fact that $10 \%$ sucrose used 3 times a day is not a high cariogenic challenge. Nevertheless, the effect of APF gel reducing enamel demineralization agrees with the findings of a study done under more cariogenic conditions (15). Furthermore, when the vol\% mineral found for the control and treated groups was compared with that observed in sound enamel, the $\%$ mineral loss calculated was $20 \%$ and $7 \%$, respectively. Thus, APF gel reduced the mineral loss by $13 \%$, confirming in situ the efficiency of this method to reduce caries (1). Nevertheless, no in situ effect of the application time was found because the difference of vol\% min between the APF groups treated for 1 or 4 min (Fig. 1) was not statistically significant. The lack of difference between the APF gel application times was observed up to the deepest distances evaluated, consistently with the results of previous in vitro studies $(11,12)$.

Shortening the time of professional $\mathrm{F}$ application is desirable for safety reasons considering that a certain amount of $\mathrm{F}$ is ingested during this clinical procedure. In summary, this in situ study gives support to in vitro investigations suggesting that APF gel application for 4 min does not reduce enamel demineralization more efficiently than does a 1-min application time.

\section{RESUMO}

Considerando que o efeito do tempo da aplicação profissional de flúor fosfato acidulado (FFA) na subseqüente inibição da desmineralização do esmalte dental não está claramente estabelecido, este foi avaliado em um estudo in situ, cruzado e cego. Em 3 fases de 28 dias cada uma, 15 voluntários utilizaram um dispositivo palatino contendo 4 blocos de esmalte, que foram submetidos a 3 grupos/tratamentos: não tratado (controle) e pré-tratado com FFA gel por 1 ou $4 \mathrm{~min}$. Placa dental foi acumulada sobre os blocos e 3 vezes ao dia os dispositivos foram imersos em uma solução de sacarose a $10 \%$ simulando um desafio cariogênico. Após cada fase, os blocos foram removidos para avaliação da desmineralização do esmalte e concentração de fluoreto $(F)$ remanescente após o desafio cariogênico. $\mathrm{O} F$ formado no esmalte foi determinado em blocos adicionais submetidos apenas à aplicação de FFA gel. O tratamento com FFA gel reduziu a desmineralização do esmalte $(p<0,05)$, independentemente do tempo de aplicação ( $p>0,05)$. Adicionalmente, a concentração de $\mathrm{F}$ formado e retido no esmalte foi significantemente maior após a aplicação do FFA gel $(p<0,05)$, mas o efeito do tempo de aplicação não foi estatisticamente significante $(p>0,05)$. Os resultados sugerem que não há diferença entre os tempos 1 ou 4 min de aplicação de FFA gel em termos de aumento da concentração de F no esmalte e redução de sua desmineralização frente a um desafio cariogênico. 


\section{ACKNOWLEDGEMENTS}

To the volunteers who participated in the study, to Mariza de Jesus Carlos Soares, Piracicaba Dental School, UNICAMP, for the technical assistance, and to Dr. Adriana Franco Paes Leme for the help with the figures. This publication was based on a thesis submitted by the first author to the Dental School of the University of São Paulo (FOUSP) in partial fulfillment of the requirements for a Doctorate Degree in Pediatric Dentistry. This study was supported by FAPESP (Proc. 96/0188-2) and the first author received a scholarship from the Brazilian Government (CAPES).

\section{REFERENCES}

1. Marinho VC, Higgins JP, Logan S, Sheiham A. Fluoride gels for preventing dental caries in children and adolescents. Cochrane Database Syst Rev 2002;2:CD002280.

2. Ripa LW. An evaluation of the use of professional (operatorapplied) topical fluorides. J Dent Res 1990;69:Spec Iss:786-796.

3. Knutson JW. Sodium fluoride solutions: Technic for application to the teeth. J Am Dent Ass 1948;36:37-39.

4. Chan JT, Warren DP, Henson HA. Use of in-office fluorides in the Greater Houston area. J Gt Houst Dent Soc 1996;68:22-24

5. ADA Council on Scientific Affairs. Professionally applied topical fluoride: evidence-based clinical recommendations. J Am Dent Assoc 2006;137:1151-1159.

6. Wefel JS, Wei SHY. In vitro evaluation of fluoride uptake from a tixotropic gel. Pediatr Dent 1979;1:97-99.

7. Wei SHY, Lau EWS, Hattab FN. Time dependence of enamel fluoride acquisition from APF gels. II. In vivo study. Pediatr Dent 1988;10:173-177.

8. ten Cate JM, Simons YM, van-Strijp AJ. Relation between enamel fluoride retention and time of topical treatment. An in situ study. J
Dent Res 1988;67:114 (Abstract 12).

9. Hebling J, Santos-Pinto LM, Cury JA. Calcium fluoride formation on human enamel by APF gels: effect of application time. Rev Bras Odontol 1995;52:30-35.

10. Tenuta LM, Cerezetti RV, Del Bel Cury AA, Tabchoury CP, Cury JA. Fluoride release from $\mathrm{CaF}_{2}$ and enamel demineralization. J Dent Res 2008;87:1032-1036.

11. Garcia-Godoy F, Hicks MJ, Flaitz CM, Berg JH. Acidulated phosphate fluoride treatment and formation of caries-like lesions in enamel. Effect of application time. J Clin Pediatr Dent 1995;19:105-110.

12. Delbem ACB, Cury JA. Effect of application time of APF and $\mathrm{NaF}$ gels on microhardness and fluoride uptake of in vitro enamel caries. Am J Dent 2002;15:169-172.

13. Altenburger MJ, Schirrmeister JF, Lussi A, Klasser M, Hellwig. In situ fluoride retention and remineralization of incipient carious lesions after the application of different concentrations of fluoride Eur J Oral Sci 2009;117:58-63.

14. Cury JA, Rebelo MAB, Del Bel Cury AA, Derbyshire MTVC, Tabchoury CPM. Biochemical composition and cariogenicity of dental plaque formed in the presence of sucrose or glucose and fructose. Caries Res 2000;34:491-497.

15. Paes Leme AF, Dalcico R, Tabchoury CPM, Del Bel Cury AA, Rosalen PL, Cury JA. In situ effect of frequent sucrose exposure on enamel demineralization and on plaque composition after APF application and F-dentifrice use. J Dent Res 2004;83:71-75.

16. Featherstone JDB, ten Cate JM, Shariati M, Arends J. Comparison of artificial caries-like lesions by quantitative microradiography and microhardness profiles. Caries Res 1983;17:385-391.

17. Moi PM, Tenuta LMA, Cury JA. Anticaries potential of a fluoride mouthrinse evaluated in vitro by validated protocols. Braz Dent J 2008;19:91-96.

18. Maia LC, Sousa IPR, Cury JA. Effects of combination of fluoride dentifrice and varnish on enamel surface rehardening and fluoride uptake in vitro. Eur J Oral Sci 2003;111:68-72.

19. Zero DT. In situ caries models. Adv Dent Res 1995;3:214-230

20. Delbem ACB, Carvalho LPR, Morihisa RKU, Cury JA. Effect of rinsing with water immediately after APF gel application on enamel demineralization in situ. Caries Res 2005;39:258-260.

Accepted February 9, 2009 